Brit. J. vener. Dis. (1956), 32, 231.

\title{
VENEREAL DISEASES CAMPAIGN IN CHILE*† ORGANIZATION AND RESULTS
}

\author{
BY \\ WALDEMAR E. COUTTS, FLORENCJO PRATS, ROBERTO VARGAS-ZALAZAR, \\ AND LUIS INFANTE-VARAS \\ School of Medicine, Chile University, and National Health Service of Chile
}

The Supreme Decree 440 of March 23, 1943, ordered the coordination of antivenereal activities and placed all the separate organizations, including the Antivenereal Dispensaries of the Public Health Service, the Social Assurance Law, and the Beneficence Hospitals, under the direct responsibility of a national committee formed by representatives of the coordinated entities. From this date all medical, epidemiological, and other activities throughout the country were unified by technical and administrative orders issued by this committee. These orders have been twice modified as regards the treatment of venereal diseases first because of the advent of penicillin and later on account of the introduction of antibiotics.

\section{SYPHILIS}

Before the enforcement of Decree 440, and since 1938, mass treatment centres for early syphilis, organized by one or other of the coordinated organizations, had been opened in several important towns (Santiago, Valparaiso, Talcahuano, Rancagua, etc.). Altogether 5,500 patients of both sexes in the primary or secondary stage of the disease were treated, the mortality rate being 0.52 per cent. The incidence curve then started to descend.

Shortly after the antisyphilitic value of penicillin was reported, the drug was added to the therapeutic arsenal of the campaign, but only slowly at finst because of its scarcity and high cost. In 1948, however, PAM was imported in sufficient quantity to allow its administration to all cases of primary or secondary syphilis. The mass treatment centres were closed and ambulatory treatment of the disease with arsenicals and other antisyphilitic drugs was re-established.

* Received for publication May 23, 1956.

t Invited article.
A total dosage of $3,000,000$ units, in two injections of 1,500,000 units given at an interval of 72 hours, was recommended for adolescents and adults. Patients in transit or from distant rural areas received the total dose in injections of $1,500,000$ units into each buttock in one session. Traced contacts immediately received penicillin as if they were infected cases. In patients with dark-field negative ulceration, blood was drawn for a serological test and the same treatment as if $T$. pallidum had been found was immediately given. Some of these measures may appear unorthodox from a strictly scientific point of view, but for many reasons they are useful from the epidemiological aspect.

The Figure (overleaf) shows the decline in cases of early syphilis. This decline started with the isolation and sterilization of infected cases in the mass treatment centres and was later facilitated by the use of penicillin. The satisfactory results are evident not only in early, but also in congenital syphilis, and in the results of serological tests of non-venereal groups of certain poorer classes of the population of the capital, Santiago (see Table).

SEROLOGIC TESTS IN SANTIAGO

\begin{tabular}{|c|c|c|c|c|c|c|c|c|}
\hline \multirow{3}{*}{ Year } & \multirow{3}{*}{$\begin{array}{l}\text { Total } \\
\text { Tests }\end{array}$} & \multirow{2}{*}{\multicolumn{2}{|c|}{$\frac{\text { Men }}{\text { Positive }}$}} & \multicolumn{3}{|c|}{ Women } & \multicolumn{2}{|c|}{ Both Sexes } \\
\hline & & & & \multirow{2}{*}{$\begin{array}{l}\text { Total } \\
\text { Tests }\end{array}$} & \multicolumn{2}{|c|}{ Positive } & \multirow{2}{*}{$\begin{array}{l}\text { Total } \\
\text { Tests }\end{array}$} & \multirow{2}{*}{$\begin{array}{l}\text { Posi- } \\
\text { tive } \\
\text { (per } \\
\text { cent.) }\end{array}$} \\
\hline & & No. & $\begin{array}{c}\text { Per } \\
\text { cent. }\end{array}$ & & No. & $\begin{array}{c}\text { Per } \\
\text { cent. }\end{array}$ & & \\
\hline $\begin{array}{l}1950 \\
1951 \\
1952 \\
1953 \\
1954 \\
1955\end{array}$ & $\begin{array}{l}9,150 \\
8,710 \\
6,432 \\
8,209 \\
7,786 \\
7,141\end{array}$ & $\begin{array}{l}617 \\
352 \\
281 \\
289 \\
125 \\
150\end{array}$ & $\begin{array}{l}6 \cdot 9 \\
4 \cdot 0 \\
4 \cdot 3 \\
3 \cdot 5 \\
1 \cdot 6 \\
2 \cdot 0\end{array}$ & $\begin{array}{r}11,415 \\
9,927 \\
8,184 \\
9,812 \\
9,371 \\
8,980\end{array}$ & $\begin{array}{r}1,028 \\
349 \\
323 \\
377 \\
254 \\
200\end{array}$ & $\begin{array}{l}9 \cdot 0 \\
3 \cdot 5 \\
3 \cdot 9 \\
3 \cdot 8 \\
2 \cdot 7 \\
2 \cdot 2\end{array}$ & $\begin{array}{l}20,565 \\
18,637 \\
14,616 \\
18,021 \\
17,157 \\
16,121\end{array}$ & $\begin{array}{l}7 \cdot 9 \\
3 \cdot 7 \\
4 \cdot 7 \\
3 \cdot 7 \\
2 \cdot 2 \\
2 \cdot 1\end{array}$ \\
\hline
\end{tabular}

\section{GonORRHOEA}

Although the number of cases of gonorrhoea has also diminished considerably, the decline is less 


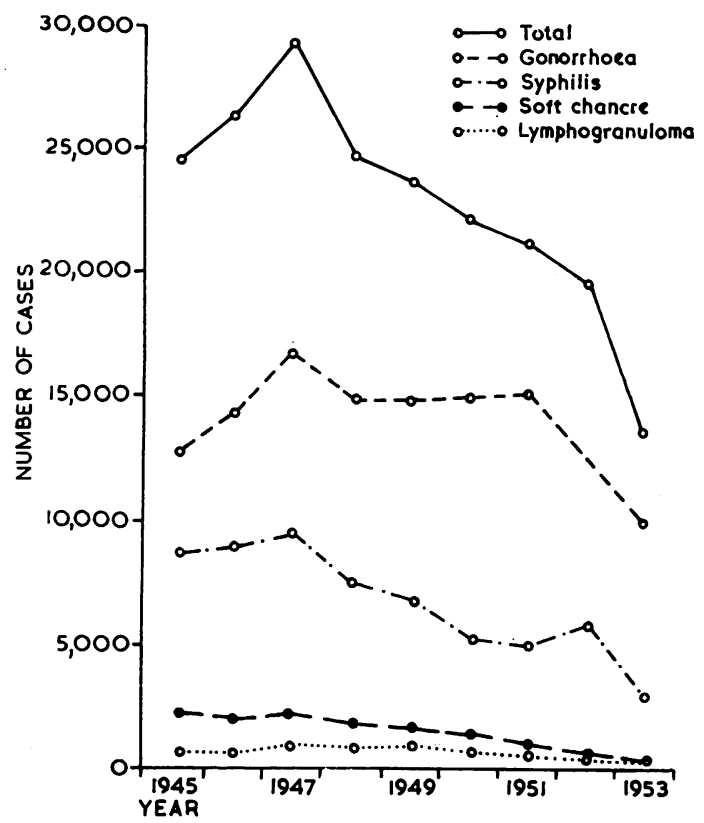

FIGURE.- Venereal morbidity in Chile (1945-1953) showing all stages

marked than that of syphilis. The curve in the Figure refers to patients of the poorer classes and does not reflect the situation among private patients, but specialists questioned on this point uniformly state that private patients with a gonococcal discharge are very seldom seen at present. We have also noted a very marked decrease in cases of acute gonococcal epididymitis and of gonococcal arthritis in hospital wards. We are convinced that, when a more careful bacteriological investigation can be made in the smaller towns, the number of cases diagnosed as gonorrhoea will gradually become less.

Acute or sub-acute gonococcal urethritis is treated with penicillin-300,000 to 600,000 units aqueous crystalline penicillin in two injections. We have not obtained satisfactory results with PAM. Aureomycin by mouth, in combination with penicillin or alone, is also used in doses of $500 \mathrm{mg}$. every 6 hours for 48 hours. Satisfactory results have been obtained in 90 per cent. of cases. In the remaining 10 per cent., if the smears are still positive for Gram-negative diplococci, a second course of treatment similar to the first is given, and from $80-90$ per cent. of these cases have been cured. In those in which Gramnegative diplococci still persist a culture of the secretion is made for identification of Neisseriae. So far we have not encountered a case that might have been considered as due to a penicillin-resistant gonococcus.

Soft Chancre and Lymphogranuloma Venereum

The frequency of soft chancre has also diminished; we seldom see a bubo of this nature and the same may be said of lymphogranuloma venereum. Later stages-esthiomene, elephantiasis of the penis and scrotum, rectal stenosis, etc.- are still seen in dispensaries or hospital wards, but the patients are generally over 40 years of age, and most of these cases probably result from infection acquired many years ago.

\section{Non-Gonococcal Genital Infections}

The number of cases of non-gonococcal urethritis or vaginitis is rapidly increasing and, at present, represent nearly 45 per cent. of those with genital discharges. Trichomonas vaginalis is the most commonly found pathogen. As $T$. vaginalis and lymphogranuloma venereum virus can produce epididymitis, the social importance of these infections is not underrated by us.

\section{CONCLUSION}

We attribute the satisfactory results of the Antivenereal Campaign in Chile to the uniformity of effort in epidemiological treatment and administration. We do not minimize the unknown help received from antibiotics administered for causes other than venereal diseases in foci of infection, both in incubation and in contacts. A careful inquiry into over 3,000 non-venereal patients visiting our Blood Test Centres for a serological test for syphilis in order to obtain a municipal license, revealed that slightly over 60 per cent. had been treated for a non-venereal cause with some kind of antibiotic, principally penicillin. 